\title{
Determinants of SME export performance
}

\author{
Muhammad Imran*, Azelin Aziz and Siti Norasyikin Abdul Hamid
}

\begin{tabular}{l} 
School of Business Management, Univers \\
\hline C H R O N I C L E \\
\hline Article history: \\
Received: October 1, 2017 \\
Received in revised format: No- \\
vember 16, 2017 \\
Accepted: May 21, 2018 \\
Available online: \\
May 21, 2018 \\
\hline Keywords: \\
Export performance \\
Pilot study \\
Small and medium enterprises \\
The Manufacturing sector \\
Pakistan
\end{tabular}

\section{Introduction}

Exporting is considered important activity for the development of countries' economy (Imran et al., 2017). The export activity maximizes the country's foreign exchange and revenue reserves (Malhotra \& Kumari, 2016). However, the term performance is not new in the strategic management study, such as the export performance of the house. Export performance includes export effectiveness, export efficiency, and continuous export engagement in exporting (Shoham, 1998) and can be measured either to investigate the financial variable or non-financial variables (Zou \& Stan, 1998). In respect to small and medium enterprises (SMEs) export performance has been investigated by various studies that how the SMEs providing value to owners, customers and country (Gupta et al., 2017). Overall, the SMEs current business scenario is under high competitive pressure due to more sophisticated market and shifting customer preferences (Stouraitis et al., 2017). In respect of developing nations such as Pakistan SMEs contribute 78 percent to non-agricultural labour force, 30 percent to gross domestic product (GDP), and 25 percent to exports business, respectively (Raziq et al., 2017).

* Corresponding author.

E-mail address: Iimran.imranb2001@gmail.com (M. Imran)

(C) 2017 by the authors; licensee Growing Science, Canada. doi: $10.5267 /$ j.ijdns.2017.1.007 
Furthermore, in view of comparison with neighbouring countries, the Pakistan SMEs contribution to GDP is higher than India (37.5 percent), less than China (60 percent) (Thaver \& Alamgir, 2014) and less than Iran (50 percent), respectively (Abdin, 2017). Additionally, Dar et al. (2017) reported that Pakistan's SMEs are performing low as compared to other developing countries, for instance, Malaysia, Thailand, China, Taiwan and Indonesia. Regardless, the nature of the nation's economy, SMEs make a great contribution to innovation, regional development and social cohesion, which in turn significantly contribute to the GDP, employment and exports as well (Abdul et al., 2011; Rehman, 2016; Shaikh et al., 2011). However, in today's highly competitive business environment that SMEs are seeking for strategies to improve their performance specifically in term of exports contribution, especially in context of Pakistan, whereas SMEs are performing low export performance (Imran et al., 2016). Numerous studies investigated the antecedents of SME export performance such as export orientation (Filatotchev et al., 2009); firm size, business experience and export intensity (Majocchi et al., 2005); development capabilities (Lefebvre et al., 1998); perceived uncertainty, Business networks (Babakus et al., 2006); cooperative strategy, knowledge intensity (Haahti et al., 2005); entrepreneurial orientation, firm management commitment (Mostafa et al., 2005); human capital (Javalgi \& Todd, 2011); social networks (Zhou et al., 2007); trade promotion (Wilkinson \& Brouthers, 2006); marketing strategy (Lages \& Montgomery, 2004); innovation (D’Angelo, 2012); information technology (Zhang et al., 2008); government assistantship (Shamsuddoha et al., 2009) and relationship quality (Ural, 2009).

More importantly, as per literature, some of factors have considered influential contributory role in SME export performance, such as entrepreneurial orientation (Amin et al., 2016; Boso et al., 2016; Cadogan et al., 2016b; Felzensztein et al., 2015; Imran et al., 2018); export market orientation (Cadogan et al., 2016b; Imran et al., 2017; Samson \& Mahmood, 2015; Singh \& Mahmood, 2013); business network (Ajayi, 2016; Imran et al., 2017; Serrano et al., 2016; Shneor et al., 2016; Yan et al., 2017) and total quality management (Abeykoon \& de Alwis, 2016; M. Imran et al., 2018; Imran et al., 2018; Lages et al., 2009). Furthermore, entrepreneurial orientation (EO) is a managerial capability which firms embark on innovation, proactiveness and risk-taking initiatives to sustain the competitive advantage, which leads to higher export performance (Imran et al., 2017; İpek, 2017). More specifically, EO behaviors for manufacturing firms are real important to help the execution of total quality management (TQM) for improving and increased the manufacturing productivity and competitive advantage (Demirbag et al., 2006; M. Imran et al., 2018; Rahman, 2001). Furthermore, SMEs are largely dependent on business network for access to international markets (Musteen et al., 2014). Moreover, in respect of export market orientation (EMO) that identify and meets the international customer's desires through products which leads to higher export performance (Cadogan et al., 2016a).

Therefore, the limited studies have been investigated the combine effect of entrepreneurial orientation, export market orientation, business network and total quality management on SME export performance, especially in the context of Pakistan (Chen et al., 2016). Furthermore, the resource base view theory suggested that the bundle of resources lead to sustainable advantage which leads to higher export performance (İpek, 2017). Thus, the current study is going to investigate the influence of entrepreneurial orientation, export market orientation, business network, total quality management on SME export performance in the context of Pakistan where observed the low SME export performance.

\section{Literature review}

The role of small and medium business in countries exports cannot deny. Any country exports relaying on small and large firm's participation. According to Dana, 2016 country exports can have enhanced very fast through large participation of SMEs. In particular, SMEs are easy to start the business, required low capital, easy to manage, the source of innovation and risk-taking for new opportunities (Dar et al., 2017). These features are gaining countries' intention to produce more and more small and medium business, which are beneficial for country exports (Rehman, 2016). Such as China they increased the export 
volume through large participation of small and medium business, nowadays China is the biggest exporter in the world (Muller et al., 2015). The participation of Pakistan' SMEs in exports is very low such as $30 \%$ of GDP and $25 \%$ in country exports (Yoshino \& Wignaraja, 2015). All the same, this contribution is very low compared to a regional competitor such as in terms of GDP contribution is higher than India's (37.5\%) and behind of China's (60\%) and Japan's (55\%) and Iran (50\%) respectively. Declining in exports, causing trade deficit and failure to fulfil trade quota and it is now becoming a burden on the economy (Hamza, 2016; Munir, 2016).

Pakistan SMEs have a potential and opportunity to improve their performance, specifically in term of export participation (Nation, 2016). Moreover, Government of Pakistan taking priority steps for the betterment of SMEs, they believe SMEs has potential to achieve the country highest export target mission 2025, it estimated around 30 billion USD exports per year (LCCI, 2017). Currently, Pakistan total export is FY 2016 \$ 17.32 billion, which is very low compared to previous years such as in FY 2014 exports was recorded as 21.21 \$ billion, in FY 2015 it dropped to \$ 19.55 billion, and further decreased in FY 2016, which is lowest in Pakistan history of the modern era (PBS, 2016). Nevertheless, there are many factors influencing the SME export performance (Chen et al., 2016). The previous studies found an absence of total quality management (Haroon \& Shariff, 2016; Latif et al., 2014; Saeed \& Hasnu, 2011), market orientation (Asad et al., 2016; Hussain et al., 2016) in the manufacturing sector of Pakistan. Moreover, they indicated that owners of SMEs and Government of Pakistan should consider these factors for SME better performance.

De Clercq and Zhou (2014) stated that entrepreneurial orientation is a process to capture the product and market introduction, market risk and seek the new opportunities for fast success. Most of the studies operationalized the entrepreneurial orientation in three dimensions such as introduction, risk-taking and proactiveness (Ajayi, 2016; Covin \& Miles, 1999; Ahimbisibwe \& Abaho, 2013; Imran et al., 2017). Moreover, various researchers have shown that entrepreneurial orientation is one of the main contributory resource in SME export performance (Abiodun \& Rosli, 2014; Fernández-Mesa \& Alegre, 2015; Samson \& Mahmood, 2015).

Export market orientation is the steadfast ability to understand the market changes regarding customer needs and wants, this ability providing source of market competitive advantage which attain to superior firm export performance (Styles et al., 2006). The operationalization of the export market orientation focused on three behavioural dimensions such as export market information generation, export market information dissemination and export market responsiveness (Cadogan et al., 2009). There are many studies found positive links between export market orientation and SME export performance, they establish a main contributing resource in SME export performance (Cadogan et al., 2016a; Chang \& Fang, 2015; Chung, 2012).

Business network is the firm resource, which is providing a path to access for market information, advanced technology, new knowledge, human and financial capital (Ginting, 2015). The business network intervening the connections among organizations and cooperation between individuals and firms (Brass et al., 2004). "If SMEs are to survive increasing global competition, they must rely on the benefits of scale and scope economies, only possible through cooperative organizations, such as bonds and networks" (Dana et al., 1999). Nevertheless, business network operationalization as in four dimensions which are information acquisition, opportunity enabling, strong tie relationship resources mobilization and weak tie relationship resources mobilization (Thornton et al., 2013, 2014, 2015). In conditions, the business network contribution in SME export performance investigated some of the researcher and they initiate that business networks highly beneficial for SME export performance (Ajayi, 2016; Ginting, 2015; Jin \& Jung, 2016).

Furthermore, total quality management is a process to improve the firm's products, procedures, and services to achieve the customer satisfaction at a low cost, which lead to higher export performance (M 
Imran et al., 2018; Kanji, 1990). The operationalization of total quality management is not thus far developed, subsequently, researchers operationalized the TQM on the theme of TQM practices, some of studies operationalized base on TQM models such as Malcolm Baldrige National Quality Award (MBNQA) and European Foundation for Quality Management (EFQM) (Jafari, 2013). Moreover, a most famous model which got more intention is a European Foundation for Quality Management (EFQM), this is more applicable in the valuation of the firm performance (M. Imran et al., 2018; M Imran et al., 2018; Shafiq et al., 2017). Nevertheless, some of the researchers found a positive connection between total quality management and export performance and further they suggested that TQM can be an influential resource for SME export performance, especially in context of Pakistan (Abeykoon \& de Alwis, 2016; M. Imran et al., 2018; M Imran et al., 2018; Lages et al., 2009). Hence, the current study proposes the following hypothesis:

$\mathbf{H}_{1}$ : There is relationship between EO and SME export performance

$\mathbf{H}_{2}$ : There is relationship between TQM and SME export performance

$\mathrm{H}_{3}$ : There is relationship between $\mathrm{BN}$ and SME export performance

$\mathbf{H}_{4}$ : There is relationship between EMO and SME export performance

\section{Research methodology}

The survey identified the six thousand nine hundred ninety-four (6994) manufacturing small and medium exporting companies in the Pakistan. By referring the Krejcie and Morgan (1970) table, study was selected three hundred sixty-four (364) manufacturing exporting SMEs for the study sample size. The study used the structured questionnaire with seven-point Likert scale. Moreover, the unit of analysis considered the firm level and targeted the company export manager as survey respondent (Calantone et al., 2004). The study scale adapted from past studies such as total quality management (Shafiq et al., 2017); entrepreneurial orientation (Boso et al., 2012); export market orientation (Cadogan et al., 2001) and business network (Thornton et al., 2014). Furthermore, the content and face validity was conducted to remove and fix any doubts regarding questionnaire/scale reliability and validity that make sure the scale is easy to read and relevant to industry characteristics. However, study conducted the reliability test to use the Cronbach alpha criteria (Sekaran \& Bougie, 2016) to validate the scale reliability. The SPSS 21 statistical software was employed to conduct the Cronbach alpha reliability analysis. Furthermore, the experts' opinion was taken regarding the scale face and content validity i.e. items are clear and items measure the right construct. Experts included senior's lecturer, assistant professor from the School of Business Management, Universiti Utara Malaysia, Malaysia, and professor from school of business administration, South China University of Technology, China. Further, few questionnaires were given to SMEs ownermanager. However, a total of three hundred sixty-four (364) e-mails sent to targeted manufacturing exporting SMEs and only forty-five (45) firms responded to the survey with a response rate of $12.36 \%$.

\section{Results and discussion}

\subsection{Validity Analysis}

Expert opinion was held considering the scale face and content validity that items can read clarity and items can measure the right build. Based on expert's opinion some of items were rewrite and double barrel questions solved correctly. The final questionnaire can be viewed in the appendix (1).

\subsection{Reliability Analysis}

The reliability test was conducted and found the all construct reliable within the Cronbach alpha threshold, the value of the constructs recorder more than 0.70 . The current study calculated the Cronbach-Alpha to find out, "internal consistency" of the data. According to George and Mallery (2003) presented the rule of deciding the Cronbach alpha value range, " $\alpha>0$.9- Excellent, $\alpha<0.8$-Good, $\alpha<0.7$ - Acceptable". 
In the study of Sekaran and Bougie (2016) stated that the value of Cronbach alpha less than 0.60 is poor, at range of 0.70 is acceptable, and 0.80 value is considered good". Thus, all constructs Cronbach alpha values found more than threshold value 0.70 . The results can be seen in table (1).

Table 1

Reliability Test

\begin{tabular}{lcc}
\hline Construct & Number of items & Cronbach's alpha \\
\hline SME export performance & 9 & .917 \\
Entrepreneurial Orientation & 13 & .917 \\
Export Market Orientation & 13 & .823 \\
Business Networks & 16 & .933 \\
Total Quality Management & 30 & .941 \\
\hline Total & 81 & \\
\hline
\end{tabular}

Furthermore, descriptive analysis was examined the industry and respondent characteristics. However, according to figure one that with respect to the nature of the business, $35.6 \%$ firms engaged in the textile business, $11.1 \%$ in surgical business, $6.7 \%$ in sports, $2.2 \%$ of leather products, $13.3 \%$ of Automobile parts, $13.3 \%$ in Electrical appliances such as Fans, and 17.8\% involved in the furniture business.

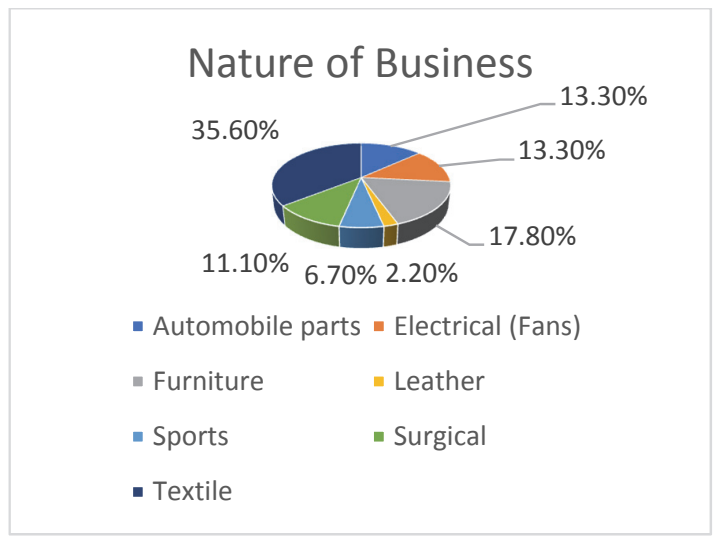

Fig. 1. Nature of Business

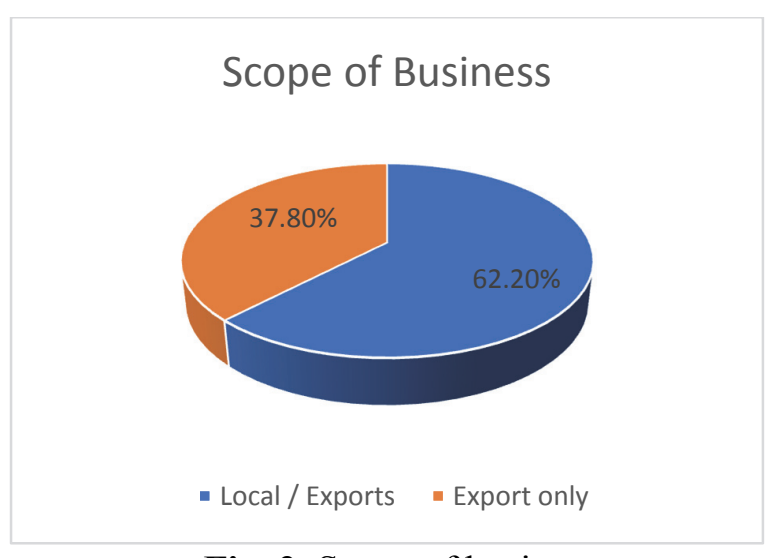

Fig. 2. Scope of business

Moreover, figure two stated the business scope $62.2 \%$ firms doing both kinds of business, mean export and local market and $37.8 \%$ firm only focused the export business. Moreover, figure three presented the respondent age, $28.9 \%$ of respondent age recorded between 31 to 40 years, $26.7 \%$ observed between 41 to 50 years, $28.9 \%$ noticed between 20 to 30 years and $15.6 \%$ funded above 50 years.

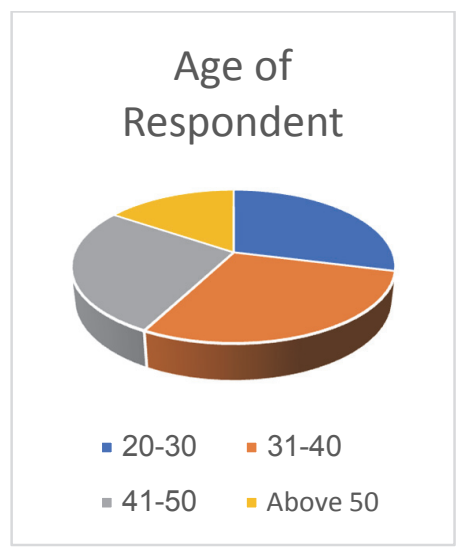

Fig. 3. Age of respondent

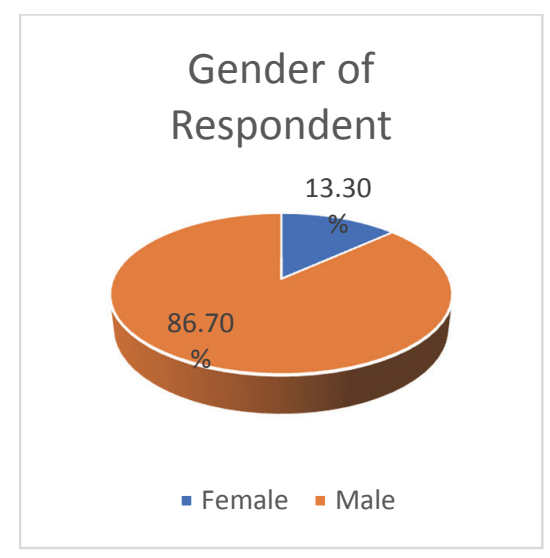

Fig. 4. Gender of respondent

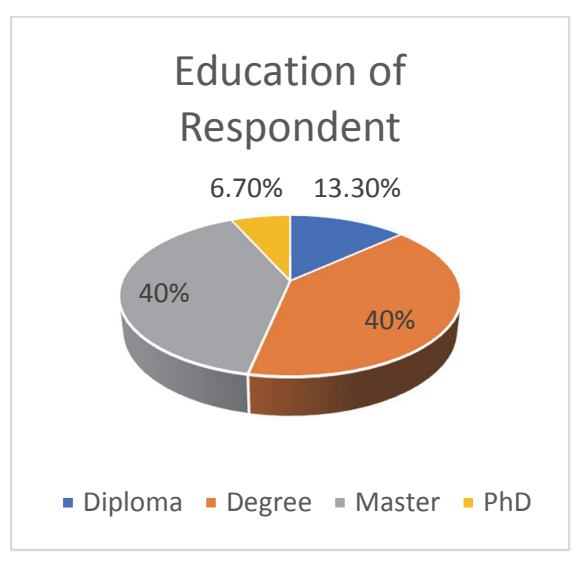

Fig. 5. Education of respondent 
In figure four explained the respondent gender, $86.7 \%$ founded male and only $13.3 \%$ belonged to a female, mean this resulted shown the male dominant culture.

In last figure five presented the respondent educational level, most of the respondent responded to master and degree level, which is $40 \%, 40 \%$ respectively. However, $13.3 \%$ respondent education level is diploma, $6.7 \%$ are $\mathrm{PhD}$ level.

\subsection{Measurement Model Assessment}

SmartPLS 3 was employed to evaluate the measurement model. PLS-SEM evaluated in two-steps, such as measurement model and structural model. The measurement model validated the constructs reliability and validity and structural model evaluated the relationship between constructs.

\subsubsection{Internal consistency and convergent validity}

Nevertheless, in respect of measurement model analyses the constructs internal consistency to use the Cronbach alpha, rho and composite reliability criteria, these all three criteria have 0.70 threshold values (Nunnally \& Bernstein, 1978). Thus, the current study internal consistency of the construct found above 0.70 values in all three measures. Furthermore, convergent validity of the construct evaluated using the average variance and items loading methods to validate the constructs. The current study found the all constructs AVE values greater than 0.50 and as well as all items observed more than threshold values and meeting the AVE values of all constructs (Hair et al., 2014). The results of internal consistency and convergence validity can be seen in Fig. 6 and Table 2 .

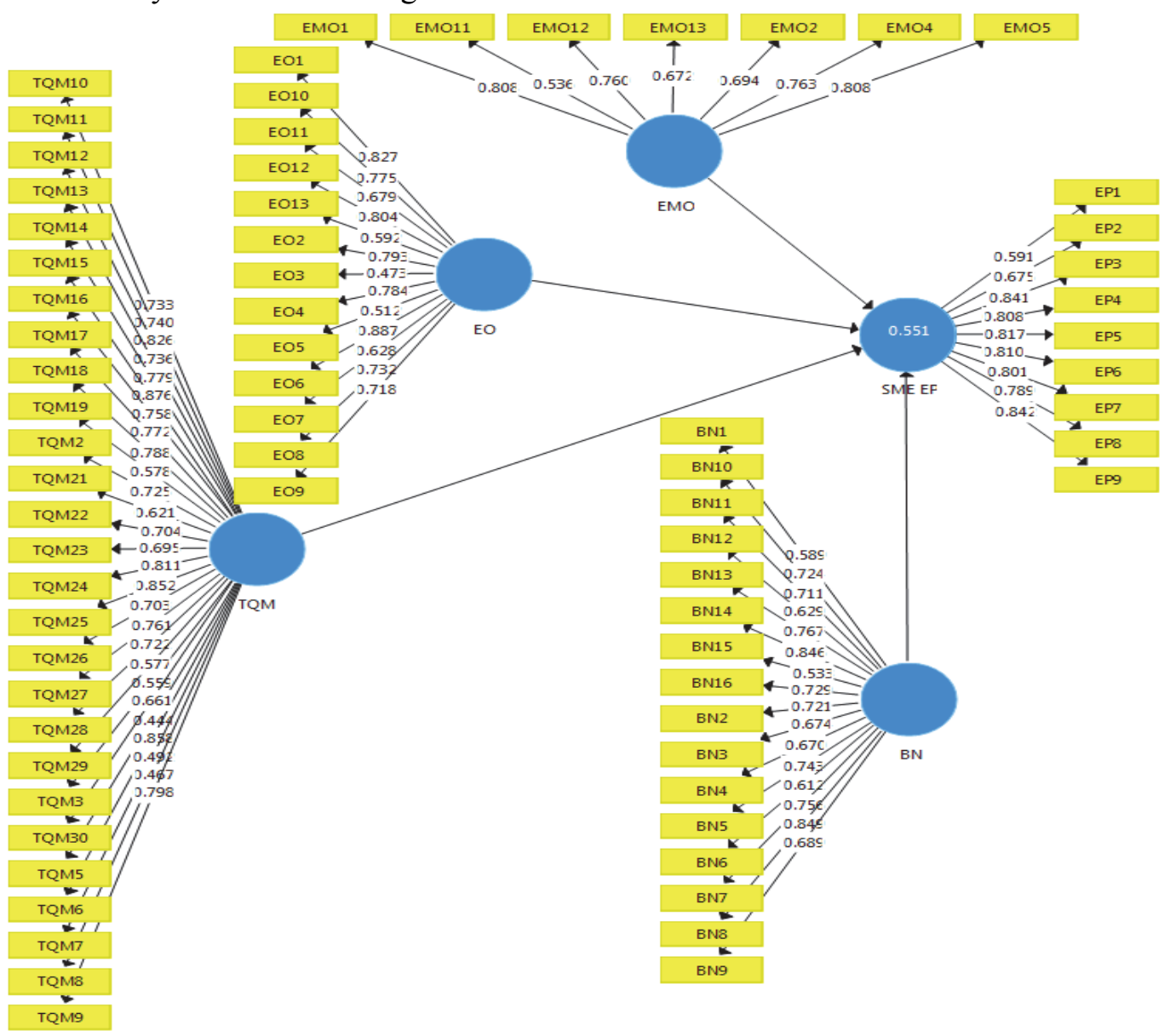

Fig. 6. Measurement model 
Table 2

Internal consistency and convergent validity

\begin{tabular}{lcccc}
\hline Constructs & Cronbach's Alpha & rho_A & Composite Reliability & Average Variance Extracted (AVE) \\
\hline EO & 0.920 & 0.940 & 0.931 & 0.516 \\
TQM & 0.961 & 0.969 & 0.965 & 0.511 \\
BN & 0.933 & 0.944 & 0.941 & 0.500 \\
EMO & 0.846 & 0.854 & 0.885 & 0.527 \\
SME EP & 0.920 & 0.938 & 0.932 & 0.607 \\
\hline
\end{tabular}

\subsubsection{Discriminant Validity}

The discriminant validity was analysed to determine the model external consistency. There are three criteria to validate the discriminant validity such as Fornell and Larcker, cross loading and HeterotraitMonotrait ratio of correlations (HTMT). According to Fornell and Larcker (1981) stated that the value of the variables was compare with the square root of AVE's. Finally, as explained in table 3 all the correlations among the variables are lower than square root-averages (AVEs) as which are bolded in crosswise.

Table 3

Fornell and Larcker

\begin{tabular}{lccccc}
\hline & BN & EMO & EO & SME EP & TQM \\
\hline BN & $\mathbf{0 . 7 0 7}$ & & & & \\
EMO & 0.76 & $\mathbf{0 . 7 2 6}$ & & & \\
EO & 0.479 & 0.713 & 0.718 & $\mathbf{0 . 7 7 9}$ & 0.617 \\
SME EP & 0.537 & 0.682 & 0.498 & 0.715 \\
TQM & 0.691 & 0.645 & & \\
\hline
\end{tabular}

In respect of cross loading, Chin (1998) stated that each indicator loading should be greater than all its cross-loadings. Otherwise, "the measure in question is unable to discriminate as to whether it belongs to the construct it was intended to measure or to another (i.e., discriminant validity problem)" (Chin, Peterson, \& Brown, 2008). However, achieve the cross loading and results can be seen in Table 4. Furthermore, the Heterotrait-Monotrait ratio of correlations (HTMT) is a new method for assessing discriminant validity in PLS-SEM, which is one of the key building blocks of model evaluation (Henseler, Ringle, \& Sarstedt, 2015). If discriminant validity is not established, researchers cannot be confirmed that the results of structural model are real, or whether they are merely the result of statistical inconsistencies. The HTMT criterion clearly outperforms standard approaches to discriminant validity assessment such as fornell and Larcker criterion and cross-loadings, which are largely unable to detect a lack of discriminant validity (Hair Jr, Hult, Ringle, \& Sarstedt, 2016). However, HTMT ratio should not be more than one (1), thus current study found the all HTMT values less than one (1) and validated all study constructs discriminant validity, results of HTMT values can be seen in Table-5.

Table 4

Cross Loadings

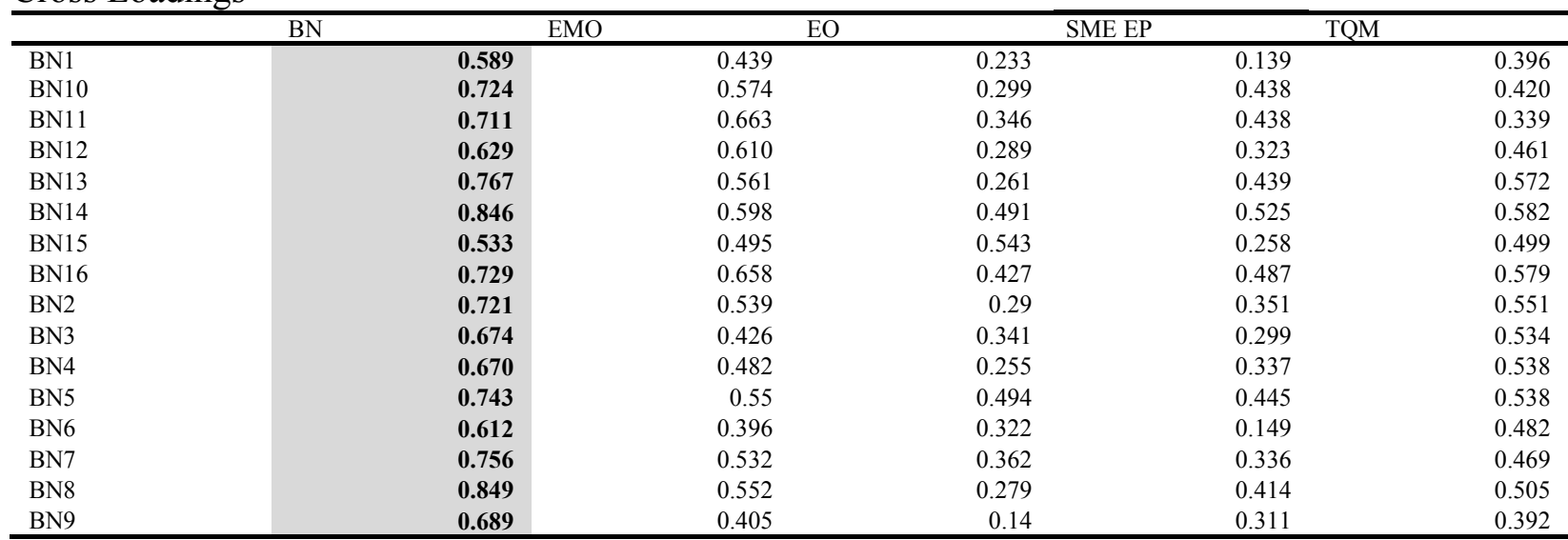


Table 4 (Continued)

Cross Loadings

\begin{tabular}{|c|c|c|c|c|c|}
\hline & $\mathrm{BN}$ & EMO & $\mathrm{EO}$ & SME EP & TQM \\
\hline EMO1 & 0.536 & 0.808 & 0.553 & 0.412 & 0.51 \\
\hline EMO11 & 0.451 & 0.536 & 0.359 & 0.411 & 0.368 \\
\hline EMO12 & 0.616 & 0.76 & 0.445 & 0.59 & 0.397 \\
\hline EMO13 & 0.398 & 0.672 & 0.557 & 0.538 & 0.448 \\
\hline EMO2 & 0.611 & 0.694 & 0.441 & 0.459 & 0.378 \\
\hline EMO4 & 0.624 & 0.763 & 0.585 & 0.42 & 0.605 \\
\hline EMO5 & 0.608 & 0.808 & 0.651 & 0.552 & 0.569 \\
\hline EO1 & 0.272 & 0.556 & 0.827 & 0.611 & 0.455 \\
\hline EO10 & 0.225 & 0.458 & 0.775 & 0.231 & 0.393 \\
\hline EO11 & 0.095 & 0.385 & 0.679 & 0.24 & 0.094 \\
\hline EO12 & 0.417 & 0.602 & 0.804 & 0.475 & 0.347 \\
\hline EO13 & 0.516 & 0.659 & 0.592 & 0.629 & 0.606 \\
\hline EO2 & 0.386 & 0.575 & 0.793 & 0.585 & 0.45 \\
\hline EO3 & 0.102 & 0.151 & 0.473 & 0.258 & -0.064 \\
\hline EO4 & 0.364 & 0.444 & 0.784 & 0.366 & 0.337 \\
\hline EO5 & 0.465 & 0.314 & 0.512 & 0.276 & 0.161 \\
\hline EO6 & 0.49 & 0.624 & 0.887 & 0.498 & 0.509 \\
\hline EO7 & 0.417 & 0.539 & 0.628 & 0.421 & 0.245 \\
\hline EO8 & 0.228 & 0.484 & 0.732 & 0.308 & 0.386 \\
\hline EO9 & 0.093 & 0.432 & 0.718 & 0.275 & 0.146 \\
\hline EP1 & 0.026 & 0.318 & 0.195 & 0.591 & 0.032 \\
\hline EP2 & 0.086 & 0.227 & 0.328 & 0.675 & 0.271 \\
\hline EP3 & 0.435 & 0.524 & 0.521 & 0.841 & 0.518 \\
\hline EP4 & 0.475 & 0.497 & 0.407 & 0.808 & 0.399 \\
\hline EP5 & 0.321 & 0.433 & 0.508 & 0.817 & 0.578 \\
\hline EP6 & 0.533 & 0.564 & 0.506 & 0.81 & 0.503 \\
\hline EP7 & 0.517 & 0.708 & 0.642 & 0.801 & 0.602 \\
\hline EP8 & 0.602 & 0.639 & 0.499 & 0.789 & 0.608 \\
\hline ЕР9 & 0.406 & 0.618 & 0.514 & 0.842 & 0.466 \\
\hline TQM10 & 0.475 & 0.429 & 0.283 & 0.309 & 0.733 \\
\hline TQM11 & 0.381 & 0.463 & 0.487 & 0.453 & 0.740 \\
\hline TQM12 & 0.46 & 0.417 & 0.381 & 0.433 & 0.826 \\
\hline TQM13 & 0.336 & 0.382 & 0.328 & 0.326 & 0.736 \\
\hline TQM14 & 0.411 & 0.482 & 0.386 & 0.502 & 0.779 \\
\hline TQM15 & 0.521 & 0.608 & 0.537 & 0.701 & 0.876 \\
\hline TQM16 & 0.443 & 0.475 & 0.262 & 0.516 & 0.758 \\
\hline TQM17 & 0.432 & 0.434 & 0.256 & 0.418 & 0.772 \\
\hline TQM18 & 0.585 & 0.553 & 0.361 & 0.55 & 0.788 \\
\hline TQM19 & 0.465 & 0.327 & 0.144 & 0.289 & 0.578 \\
\hline TQM2 & 0.535 & 0.676 & 0.689 & 0.491 & 0.725 \\
\hline TQM21 & 0.559 & 0.468 & 0.382 & 0.437 & 0.621 \\
\hline TQM22 & 0.586 & 0.461 & 0.179 & 0.443 & 0.704 \\
\hline TQM23 & 0.485 & 0.449 & 0.273 & 0.379 & 0.695 \\
\hline TQM24 & 0.729 & 0.609 & 0.364 & 0.446 & 0.811 \\
\hline TQM25 & 0.504 & 0.422 & 0.274 & 0.436 & 0.852 \\
\hline TQM26 & 0.491 & 0.439 & 0.38 & 0.358 & 0.703 \\
\hline TQM27 & 0.453 & 0.318 & 0.276 & 0.42 & 0.761 \\
\hline TQM28 & 0.446 & 0.428 & 0.395 & 0.472 & 0.722 \\
\hline TQM29 & 0.613 & 0.348 & 0.107 & 0.373 & 0.577 \\
\hline TQM3 & 0.379 & 0.419 & 0.435 & 0.324 & 0.559 \\
\hline TQM30 & 0.442 & 0.296 & 0.262 & 0.402 & 0.661 \\
\hline TQM5 & 0.54 & 0.529 & 0.336 & 0.429 & 0.444 \\
\hline TQM6 & 0.651 & 0.671 & 0.534 & 0.604 & 0.858 \\
\hline TQM7 & 0.447 & 0.402 & 0.399 & 0.324 & 0.492 \\
\hline TQM8 & 0.483 & 0.192 & 0.12 & 0.247 & 0.467 \\
\hline TQM9 & 0.407 & 0.351 & 0.461 & 0.335 & 0.798 \\
\hline
\end{tabular}

Table 5

HTMT

\begin{tabular}{llllll}
\hline & BN & EMO & EO & SME EP & TQM \\
\hline BN & & & & & \\
EMO & 0.848 & 0.764 & & \\
EO & 0.498 & 0.718 & 0.579 & 0.595 \\
SME EP & & 0.524 & 0.709 & 0.502 & 0.739 \\
TQM & 0.79 & & \\
\hline
\end{tabular}




\subsection{Structural Model Assessment}

After the measurement model evaluation, the current study runs the structural model / inner model to accept and reject the proposed hypothesis. The structural model assessment to use the path coefficient, the coefficient of determination (R2), effect size (f2), cross-validated redundancy (Q2) criteria. In a path coefficient assessment that evaluated the relationship between constructs to accept and reject the proposed hypothesis. However, for the direct relationship assessment was performed (with 5000 sub-sampling for 397 responses) to determine the beta-values and T-values. The current study was analyzed four (04) direct relationships and found the support for H2, and remaining such as H1, H3, H4 rejected. The hypothesis accepted on based on t-value, which observed greater than the threshold value of 1.96 accepted and those are less than t-value 1.96 rejected. The results presented in table 6 and figure 7.

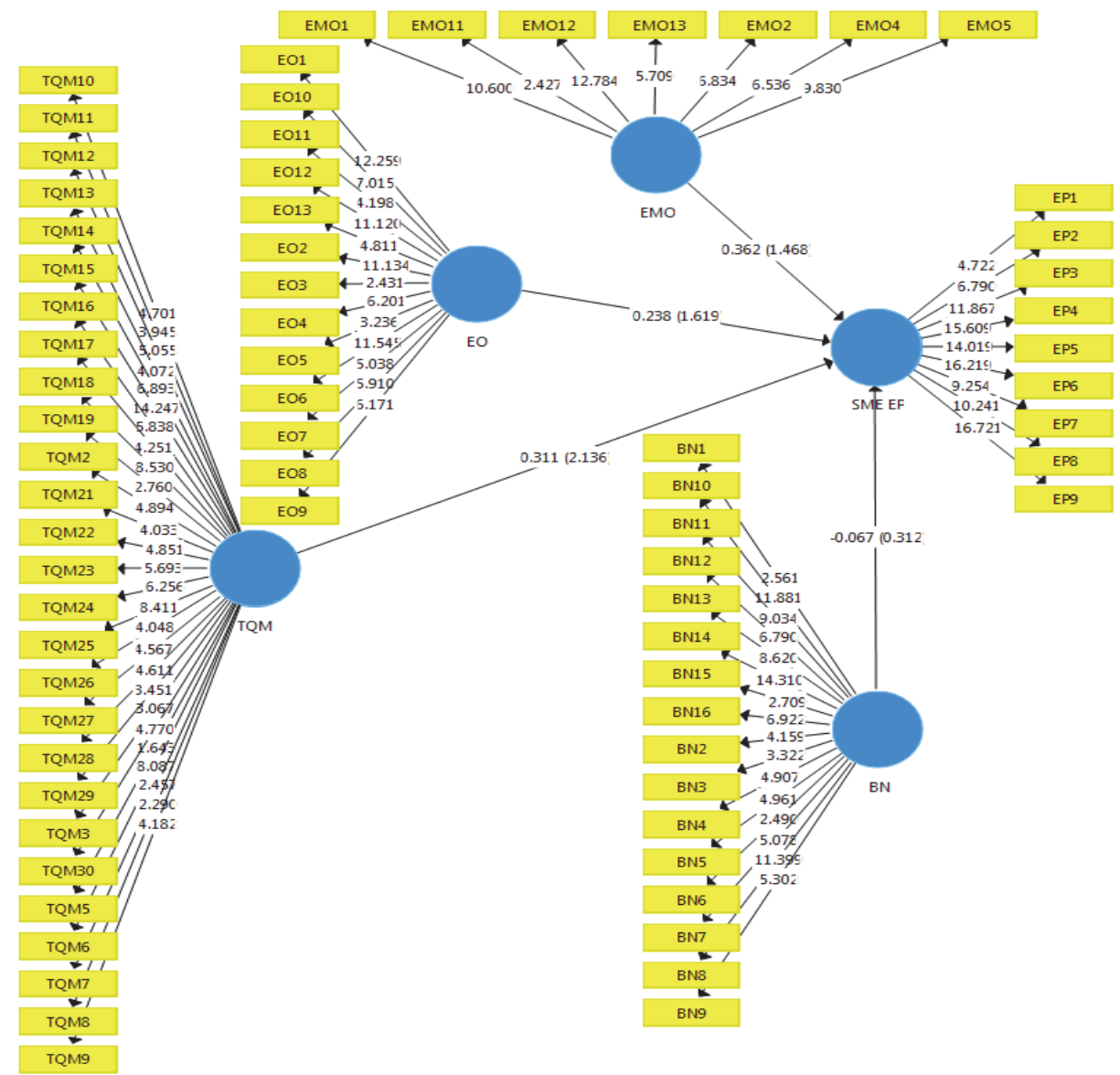

Fig. 7. Structural model

Table 6

Path co-efficient

\begin{tabular}{lcccc}
\hline Hypothesis & Beta & Standard Deviation & T Statistics & P Values \\
\hline $\mathrm{H} 1: \mathrm{EO} \rightarrow$ SME EP & 0.238 & 0.147 & 1.619 & $\mathbf{0 . 1 0 6}$ \\
$\mathrm{H} 2: \mathrm{TQM} \rightarrow$ SME EP & 0.311 & 0.146 & 2.136 & $\mathbf{0 . 0 3 3}$ \\
$\mathrm{H} 3: \mathrm{BN} \rightarrow$ SME EP & -0.067 & 0.215 & 0.312 & $\mathbf{0 . 7 5 5}$ \\
$\mathrm{H} 4: \mathrm{EMO} \rightarrow$ SME EP & 0.362 & 0.247 & 1.468 & $\mathbf{0 . 1 4 3}$ \\
\hline
\end{tabular}

Note: ${ }^{*} \mathrm{p}<0.1,{ }^{*} \mathrm{p}<0.05, \mathrm{~ns}=$ not significant $(\mathrm{p}>.05)$ (Two Tail)

The coefficient of determination $\left(R^{2}\right)$ is a major part of a structural model assessment. The $R^{2}$ is a measure of model's predictive accuracy and the value of $R^{2}$ consider as 0.25 (weak), 0.50 (moderate), and 0.70 
(strong) respectively (Hair et al., 2014). In our case, the EO TQM, BN and EMO explained 55\% of SME export performance and called moderate contribution, the results can be seen in the table- 7 .

Furthermore, the effect size is explained as the exogenous variable contribution into endogenous variable $R^{2}$ values. The values of $f^{2}$ are considered as small (0.02), medium (0.15) and large (0.35) respectively (Cohen, Cohen, West, \& Aiken, 2013). The current study found the effect size as EO-EP (0.060) small, TQM-EP (0.103) medium, BN-EP (0.003) small and EMO-EP (0.076) small, respectively. The effect size values can be seen in Table-7.

The cross-validated redundancy $\left(Q^{2}\right)$ is a means for assessing the structural model predictive relevance. According to Hair Jr et al. (2016) stated that $Q^{2}$ value larger than zero for an endogenous construct indicates the path model's predictive relevance of this construct. However, the current study model $Q^{2}$ value more than zero and found model predictive relevance. The results can be seen in table- 7 .

Table 7

Effect size $\left(f^{2}\right)$, predictive relevance $\left(R^{2}\right)$ and cross-validated redundancy $\left(Q^{2}\right)$

\begin{tabular}{lccc}
\hline Exogenous Variable & $\boldsymbol{f}^{2}$ & $\boldsymbol{R}^{2}$ & \multirow{2}{*}{$\boldsymbol{Q}^{2}$} \\
\cline { 2 - 2 } Entrepreneurial Orientation & 0.060 & \multirow{2}{*}{0.551} & \multirow{2}{*}{0.278} \\
Total Quality Management & 0.103 & & \\
Business Network & 0.003 & & \\
Export Market Orientation & 0.076 & & \\
\hline
\end{tabular}

\subsection{Importance performance matrix analysis (IPMA)}

Importance-performance matrix analysis (IPMA) assessment is helpful for researchers who employ PLSSEM to extend their findings (Hair et al., 2014). In an IPMA, latent variable scores are used to range from 0 to 100, whereby 0 indicates the lowest performance, 100 represents the highest performance, and 50 refers to the average performance. To calculate the importance and performance values of independent variables, the current study ran the IPMA algorithm of software SmartPLS 3 (Ringle, Wende, \& Becker, 2015 ) and results reported in Table-9. Nevertheless, the performance values of entrepreneurial orientation (59.830), total quality management (72.534), Business network (67.201) and export market orientation (62.503) found, respectively, thus all constructs in the study lying the average performance values. The results can be seen in Table 8 .

Table 8

Importance-performance matrix analysis

\begin{tabular}{lcc}
\hline & Importance & performance \\
\hline Entrepreneurial Orientation & 0.238 & 59.830 \\
Total Quality Management & 0.311 & 72.534 \\
Business Network & -0.067 & 67.201 \\
Export Market Orientation & 0.362 & 62.503 \\
\hline
\end{tabular}

\section{Conclusion}

The current study variables have developed for decades of years, but still there are no regular and exact definitions of these variables, even many of researchers has been done about the effects and influence of total quality management (TQM), entrepreneurial orientation (EO), business network (BN) and export market orientation (EMO) on firm performance, however, many areas are still needed to be further explored, such as firm export performance, especially in context of Pakistan.

In this current study that investigated the relationship between TQM, EO, BN, EMO and SME export performance of the manufacturing sector in Pakistan. The findings of the study show that contributory role of TQM in SME export performance and this positive significant results between TQM and SME 
export performance is consistent with previous studies (M. Imran et al., 2018; M Imran et al., 2018). On the other side, the present study found the insignificance relationship between EO, BN, EMO and SME export performance, thus these relationships result shown the least interest towards better SME export performance. Thus, manufacturing sector firms of Pakistan should reconsider the EO, BN and EMO strategies and considered these factors during decision making to SME export performance. Secondly might be possible the insignificant results between EO, BN, EMO and SME export performance happened due to very small sample size. However, these insignificant relationships are consistent with previous studies as well (Frishammar \& Andersson, 2009; Mac \& Evangelista, 2016; Shneor et al., 2016). However, according to Baron and Kenny (1986), the third variable such as a moderator or mediator should be employed if there is an inconsistent relationship was existing between criterion and predictor variables. Therefore, future studies should be considered the third variable between EO, BN, EMO and SME export performance to explain the relationship in detail. Furthermore, the current study suggests to firm managers should consider the TQM during decision making and should implement.

\section{References}

Abdin, J. (2017). SMEs and our development goals. The Daily Start. Retrieved from http://www.thedailystar.net/education-employment/smes-and-our-development-goals-1366591

Abeykoon, M., \& de Alwis, A. (2016). The Impact of Total Quality Management Practices on Export Performance of Apparel Exporters of Sri Lanka. Kelaniya Journal of Human Resource Management, 10(1).

Abiodun, T. S., \& Rosli, M. (2014). The mediating effect of reconfiguring capabilities on the relationship between entrepreneurial orientation and export performance of small and medium enterprises. European Journal of Business and Management, 6(34), 345-357.

Ajayi, B. (2016). The Impact of Entrepreneurial Orientation and Networking Capabilities on the Export Performance of Nigerian Agricultural SMEs. Journal of Entrepreneurship and Innovation in Emerging Economies, 2393957515619720.

Amin, M., Thurasamy, R., Aldakhil, A. M., \& Kaswuri, A. H. B. (2016). The effect of market orientation as a mediating variable in the relationship between entrepreneurial orientation and SMEs performance. Nankai Business Review International, 7(1), 39-59.

Asad, M., Sharif, M., Mohd, N., \& Alekam, J. M. E. (2016). MODERATING EFFECT OF ENTREPRENEURIAL NETWORKING ON THE RELATIONSHIP BETWEEN ENTREPRENEURIAL ORIENTATION AND PERFORMANCE OF MICRO AND SMALL ENTERPRISES. Science International, 28(2).

Babakus, E., Yavas, U., \& Haahti, A. (2006). Perceived uncertainty, networking and export performance: A study of Nordic SMEs. European Business Review, 18(1), 4-13.

Baron, R. M., \& Kenny, D. A. (1986). The moderator-mediator variable distinction in social psychological research: Conceptual, strategic, and statistical considerations. Journal of personality and social psychology, 51(6), 1173.

Boso, N., Cadogan, J. W., \& Story, V. M. (2012). Complementary effect of entrepreneurial and market orientations on export new product success under differing levels of competitive intensity and financial capital. International Business Review, 21(4), 667-681.

Boso, N., Oghazi, P., Cadogan, J. W., \& Story, V. M. (2016). ENTREPRENEURIAL AND MARKETORIENTED ACTIVITIES, FINANCIAL CAPITAL, ENVIRONMENT TURBULENCE, AND EXPORT PERFORMANCE IN AN EMERGING ECONOMY. Journal of Small Business Strategy, 26(1), 1.

Brass, D. J., Galaskiewicz, J., Greve, H. R., \& Tsai, W. (2004). Taking stock of networks and organizations: A multilevel perspective. Academy of Management Journal, 47(6), 795-817.

Cadogan, J. W., Boso, N., Story, V. M., \& Adeola, O. (2016a). Export strategic orientation-performance relationship: Examination of its enabling and disenabling boundary conditions. Journal of Business Research, 69(11), 5046-5052. 
Cadogan, J. W., Boso, N., Story, V. M., \& Adeola, O. (2016b). Export strategic orientation-performance relationship: Examination of its enabling and disenabling boundary conditions. Journal of Business Research.

Cadogan, J. W., Kuivalainen, O., \& Sundqvist, S. (2009). Export market-oriented behavior and export performance: quadratic and moderating effects under differing degrees of market dynamism and internationalization. Journal of international Marketing, 17(4), 71-89.

Cadogan, J. W., Paul, N. J., Salminen, R. T., Puumalainen, K., \& Sundqvist, S. (2001). Key antecedents to "export" market-oriented behaviors: a cross-national empirical examination. International Journal of Research in Marketing, 18(3), 261-282.

Calantone, R. J., Tamer Cavusgil, S., Schmidt, J. B., \& Shin, G. C. (2004). Internationalization and the dynamics of product adaptation-An empirical investigation. Journal of Product Innovation Management, 21(3), 185-198.

Chang, Y.-S., \& Fang, S.-R. (2015). Enhancing Export Performance for Business Markets: Effects of Interorganizational Relationships on Export Market Orientation (EMO). Journal of Business-toBusiness Marketing, 22(3), 211-228.

Chen, Sousa, C., \& He, X. (2016). The determinants of export performance: a review of the literature 2006-2014. International Marketing Review, 33(5), 626-670.

Chin, W. W. (1998). The partial least squares approach to structural equation modeling. Modern methods for business research, 295(2), 295-336.

Chin, W. W., Peterson, R. A., \& Brown, S. P. (2008). Structural equation modeling in marketing: Some practical reminders. Journal of Marketing Theory and Practice, 16(4), 287-298.

Chung, H. F. (2012). Export market orientation, managerial ties, and performance. International Marketing Review, 29(4), 403-423.

Cohen, J., Cohen, P., West, S. G., \& Aiken, L. S. (2013). Applied multiple regression/correlation analysis for the behavioral sciences: Routledge.

Covin, J. G., \& Miles, M. P. (1999). Corporate entrepreneurship and the pursuit of competitive advantage. Entrepreneurship: Theory and practice, 23(3), 47-47.

D'Angelo, A. (2012). Innovation and export performance: a study of Italian high-tech SMEs. Journal of management \& governance, 16(3), 393-423.

Dana, L. P., Etemad, H., \& Wright, R. W. (1999). The impact of globalization on SMEs. Global Focus, 11(4), 93-106.

Dar, M. S., Ahmed, S., \& Raziq, A. (2017). SMALL AND MEDIUM-SIZE ENTERPRISES IN PAKISTAN: DEFINITION AND CRITICAL ISSUES. Pakistan Business Review, 19(1), 46-70.

De Clercq, D., \& Zhou, L. (2014). Entrepreneurial strategic posture and performance in foreign markets: the critical role of international learning effort. Journal of international Marketing, 22(2), 47-67.

Demirbag, M., Lenny Koh, S., Tatoglu, E., \& Zaim, S. (2006). TQM and market orientation's impact on SMEs' performance. Industrial Management \& Data Systems, 106(8), 1206-1228.

Felzensztein, C., Ciravegna, L., Robson, P., \& Amorós, J. E. (2015). Networks, entrepreneurial orientation, and internationalization scope: evidence from Chilean small and medium enterprises. Journal of Small Business Management, 53(S1), 145-160.

Fernández-Mesa, A., \& Alegre, J. (2015). Entrepreneurial orientation and export intensity: Examining the interplay of organizational learning and innovation. International Business Review, 24(1), 148156.

Filatotchev, I., Liu, X., Buck, T., \& Wright, M. (2009). The export orientation and export performance of high-technology SMEs in emerging markets: The effects of knowledge transfer by returnee entrepreneurs. Journal of International Business Studies, 40(6), 1005-1021.

Filipe Lages, L., \& Montgomery, D. B. (2004). Export performance as an antecedent of export commitment and marketing strategy adaptation: Evidence from small and medium-sized exporters. European Journal of Marketing, 38(9/10), 1186-1214.

Fornell, C., \& Larcker, D. F. (1981). Evaluating structural equation models with unobservable variables and measurement error. Journal of Marketing research, 39-50. 
Frishammar, J., \& Andersson, S. (2009). The overestimated role of strategic orientations for international performance in smaller firms. Journal of International Entrepreneurship, 7(1), 57-77.

George, D., \& Mallery, M. (2003). Using SPSS for Windows step by step: a simple guide and reference. Ginting, G. (2015). NETWORK RESOURCES AS A KEY DETERMINANT OF SMALL MEDIUM ENTERPRISES/SMES EXPORT PERFORMANCE (CASE: CREATIVE INDUSTRY IN INDONESIA). International Journal of Applied Business and Economic Research, 15(7), 4867-4886.

Godwin Ahimbisibwe, M., \& Abaho, E. (2013). Export entrepreneurial orientation and export performance of SMEs in Uganda. Global Advanced Research Journal of Management and Business Studies, 2(1), 056-062.

Haahti, A., Madupu, V., Yavas, U., \& Babakus, E. (2005). Cooperative strategy, knowledge intensity and export performance of small and medium sized enterprises. Journal of world business, 40(2), 124138.

Hair, J. F., Hult, G. T. M., Ringle, C. M., \& Sarstedt, M. (2014). A Primer on Partial Least Squares Structural Equation Modeling (PLS-SEM). Los Angeles, CA: SAGE.

Hair Jr, J. F., Hult, G. T. M., Ringle, C., \& Sarstedt, M. (2016). A primer on partial least squares structural equation modeling (PLS-SEM) (2nd ed.). Thousand Oaks, CA: SAGE.

Hamza, A. (2016). Pakistan's trade deficit widens to 35-year high in FY16. Daily Times. Retrieved from http://dailytimes.com.pk/business/16-Jul-16/pakistans-trade-deficit-widens-to-35-year-high-in-fy16

Haroon, U., \& Shariff, M. N. M. (2016). THE INTERPLAY OF INNOVATION, TQM PRACTICES AND SMES PERFORMANCE IN PAKISTAN: MODERATING EFFECTS OF KNOWLEDGE INERTIA AND EXTERNAL ENVIRONMENT. South East Asia Journal of Contemporary Business, Economics and Law, 9(2).

Henseler, J., Ringle, C. M., \& Sarstedt, M. (2015). A new criterion for assessing discriminant validity in variance-based structural equation modeling. Journal of the Academy of Marketing Science, 43(1), 115-135.

Hussain, J., Rahman, W., \& Shah, F. A. (2016). Market Orientation and Performance: The Interaction Effect of Entrepreneurial Orientation. Pakistan Journal of Commerce and Social Sciences, 10(2), 388403.

Imran, M., Aziz, A., \& Hamid, S. (2016). MODERATING ROLE OF ENVIRONMENTAL TURBULENCE ON THE RELATIONSHIP BETWEEN ENTREPRENEURIAL ORIENTATION, BUSINESS NETWORKS ORIENTATION, EXPORT MARKET ORIENTATION AND SMEs EXPORT PERFORMANCE: A RESEARCH FRAMEWORK. Journal of Business Management, Commerce \& Research, IV (XV).

Imran, M., Aziz, A., \& Hamid, S. (2017). Total Quality Management, Export Market Orientation and Firm Export Performance: A Conceptual Framework. International Journal of Academic Research in Business and Social Sciences, 7(9), 591-601. doi:10.6007/IJARBSS/v7-i9/3382

Imran, M., Aziz, A., Hamid, S., Shabbir, M., Salman, R., \& Jian, Z. (2018). The mediating role of total quality management between entrepreneurial orientation and SMEs export performance. Management Science Letters, 8(6), 519-532.

Imran, M., Hamid, S., \& Aziz, A. (2018). The influence of TQM on export performance of SMEs: Empirical evidence from manufacturing sector in Pakistan using PLS-SEM. Management Science Letters, 8(5), 483-496.

İpek, İ. (2017). The Resource-Based View within the Export Context: An Integrative Review of Empirical Studies. Journal of Global Marketing, 1-23.

Jafari, H. (2013). Developing EFQM and VIKORE methods as appropriate framework for evaluating the performance of Iranian free trade zones. Applied mathematics in Engineering, Management and Technology, 1(4), 24-34.

Javalgi, R. R. G., \& Todd, P. R. (2011). Entrepreneurial orientation, management commitment, and human capital: The internationalization of SMEs in India. Journal of Business Research, 64(9), 10041010 . 
Jin, B., \& Jung, S. (2016). Toward a deeper understanding of the roles of personal and business networks and market knowledge in SMEs' international performance. Journal of Small Business and Enterprise Development, 23(3), 812-830.

Kanji, G. K. (1990). Total quality management: the second industrial revolution. Total quality management, 1(1), 3-12.

Khalique, M., Isa, A. H. B. M., Shaari, N., \& Abdul, J. (2011). Challenges for Pakistani SMEs in a knowledge-based economy. Indus Journal of Management \& Social Sciences, 5(2).

Krejcie, R. V., \& Morgan, D. W. (1970). Determining sample size for research activities. Educational and psychological measurement, 30(3), 607-610.

Lages, L. F., Silva, G., \& Styles, C. (2009). Relationship capabilities, quality, and innovation as determinants of export performance. Journal of international Marketing, 17(4), 47-70.

Latif, Y., Fiaz, M., \& Shoaib, M. (2014). Important TQM Implementation Contributors in Pakistani Petrochemical Sector. Pakistan Journal of Statistics and Operation Research, 10(3).

LCCI. (2017). Untapped Export Potentail of Pakistan. Retrieved from Lahore, Pakistan: http://www.lcci.com.pk/research-department/lccirnd/attachments/export\%20book-final.pdf

Lefebvre, E., Lefebvre, L. A., \& Bourgault, M. (1998). R\&D-related capabilities as determinants of export performance. Small Business Economics, 10(4), 365-377.

Mac, L., \& Evangelista, F. (2016). The relative impact of market orientation and entrepreneurship on export performance: do we really know enough? Journal of Global Marketing, 29(5), 266-281.

Majocchi, A., Bacchiocchi, E., \& Mayrhofer, U. (2005). Firm size, business experience and export intensity in SMEs: A longitudinal approach to complex relationships. International Business Review, 14(6), 719-738.

Malhotra, N., \& Kumari, D. (2016). Determinants of Exports in Major Asian Economies. Journal of International Economics, 7(1), 94.

Mostafa, R. H., Wheeler, C., \& Jones, M. V. (2005). Entrepreneurial orientation, commitment to the Internet and export performance in small and medium sized exporting firms. Journal of International Entrepreneurship, 3(4), 291-302.

Muller, P., Caliandro, C., Viktoriya , P., Gagliardi, D., Marzocchi, C., Ramlogan, R., \& Cox, D. (2015). European Comission: Annual Report on European SMEs 2014/2015. Retrieved from Berlin, Germany:

http://ec.europa.eu/DocsRoom/documents/16341/attachments/2/translations/en/renditions/native

Munir, A. (2016). SMEs need technology upgrade. $D A W N$. Retrieved from http://www.dawn.com/news/1242458/smes-need-technology-upgrade

Musteen, M., Datta, D. K., \& Butts, M. M. (2014). Do international networks and foreign market knowledge facilitate SME internationalization? Evidence from the Czech Republic. Entrepreneurship theory and practice, 38(4), 749-774.

Nation, T. (2016). Ahsan stresses need for non-traditional SMEs promotion. The Nation. Retrieved from http://nation.com.pk/national/18-Oct-2016/ahsan-stresses-need-for-non-traditional-smes-promotion

Nunnally, J. C., \& Bernstein, I. H. (1978). Psychometric theory.

Paul, J., Parthasarathy, S., \& Gupta, P. (2017). Exporting challenges of SMEs: A review and future research agenda. Journal of world business, 52(3), 327-342.

PBS. (2016). Export performance of Pakistan. Pakistan Bureau of Statistics Government of Pakistan Retrieved from http://www.pbs.gov.pk/.

Rahman, S.-u. (2001). Total quality management practices and business outcome: Evidence from small and medium enterprises in Western Australia. Total quality management, 12(2), 201-210.

Rehman, N. U. (2016). Network alliances and firms' performance: a panel data analysis of Pakistani SMEs. Eurasian Business Review, 6(1), 37-52.

Ringle, C. M., Wende, S., \& Becker, J.-M. (2015). SmartPLS 3. Boenningstedt: SmartPLS GmbH, http://www. smartpls. com.

Saeed, \& Hasnu, S. (2011). Total Quality Management in Exporting SME s of Pakistan: A Case Study of Sports Goods Manufacturers at Sialkot. INTERDISCIPLINARY JOURNAL OF CONTEMPORARY RESEARCH IN BUSINESS, 2(12). 
Samson, A., \& Mahmood, R. (2015). Fostering Export Performance in SMEs: The Roles of Export Market Orientation and Learning Orientation in Turbulent Environment. International Journal of Economic Perspectives, 9(2), 28.

Sekaran, U., \& Bougie, R. J. (2016). Research methods for business: A skill building approach (Vol. 7): John Wiley \& Sons.

Serrano, R., Acero, I., \& Fernandez-Olmos, M. (2016). Networks and export performance of agri-food firms: New evidence linking micro and macro determinants. Agric. Econ. - Czech, 62(10), 459-470.

Shafiq, M., Lasrado, F., \& Hafeez, K. (2017). The effect of TQM on organisational performance: empirical evidence from the textile sector of a developing country using SEM. Total Quality Management \& Business Excellence, 1-22. doi:10.1080/14783363.2017.1283211

Shah, A. A., Mehmood, T., Hashmi, M. A., Shah, S. M., \& Shaikh, F. M. (2011). Performance of SMEs in Export Growth and Its Impact on Economy of Pakistan. International Journal of Business and Management, 6(7), 287.

Shamsuddoha, A., Yunus Ali, M., \& Oly Ndubisi, N. (2009). Impact of government export assistance on internationalization of SMEs from developing nations. Journal of Enterprise Information Management, 22(4), 408-422.

Shneor, J. I. J., Tiia Vissak, R., Torkkeli, L., Kuivalainen, O., Saarenketo, S., \& Puumalainen, K. (2016). Network competence in Finnish SMEs: implications for growth. Baltic Journal of Management, 11(2), 207-230.

Shoham, A. (1998). Export performance: a conceptualization and empirical assessment. Journal of international Marketing, 59-81.

Singh, H., \& Mahmood, R. (2013). Determining the effect of export market orientation on export performance of small and medium enterprises in Malaysia: An exploratory study. Advances in Management and Applied Economics, 3(6), 223.

Stouraitis, V., Mior Harun, M. H., \& Kyritsis, M. (2017). Motivators of SME initial export choice and the European Union regional effect in manufacturing. International Journal of Entrepreneurial Behavior \& Research, 23(1), 35-55.

Styles, C., Gray, s., Kropp, F., Lindsay, N. J., \& Shoham, A. (2006). Entrepreneurial, market, and learning orientations and international entrepreneurial business venture performance in South African firms. International Marketing Review, 23(5), 504-523.

Thaver, Z., \& Alamgir, M. (2014). Progress analysis: SMEs vital to long-term sustainable growth. The Express TRIBUNE. Retrieved from http://tribune.com.pk/story/750956/progress-analysis-smes-vitalto-long-term-sustainable-growth-says-thaver/

Thornton, S. C., Henneberg, S. C., \& Naudé, P. (2013). Understanding types of organizational networking behaviors in the UK manufacturing sector. Industrial Marketing Management, 42(7), 1154-1166.

Thornton, S. C., Henneberg, S. C., \& Naudé, P. (2014). Conceptualizing and validating organizational networking as a second-order formative construct. Industrial Marketing Management, 43(6), 951-966.

Thornton, S. C., Henneberg, S. C., \& Naudé, P. (2015). An empirical investigation of network-oriented behaviors in business-to-business markets. Industrial Marketing Management, 49, 167-180.

Ural, T. (2009). The effects of relationship quality on export performance: A classification of small and medium-sized Turkish exporting firms operating in single export-market ventures. European Journal of Marketing, 43(1/2), 139-168.

Wilkinson, T., \& Brouthers, L. E. (2006). Trade promotion and SME export performance. International Business Review, 15(3), 233-252.

Yan, H., He, X., \& Cheng, B. (2017). Managerial Ties, Market Orientation, and Export Performance: Chinese Firms Experience. Management and Organization Review, 1-28.

Yoshino, N., \& Wignaraja, G. (2015). SMEs Internationalization and

Finance in Asia. Retrieved from https://www.imf.org/external/np/seminars/eng/2015/jica2015/pdf/1-B1.pdf

Zhang, M., Sarker, S., \& Sarker, S. (2008). Unpacking the effect of IT capability on the performance of export-focused SMEs: a report from China. Information Systems Journal, 18(4), 357-380. 
Zhou, L., Wu, W.-p., \& Luo, X. (2007). Internationalization and the performance of born-global SMEs: the mediating role of social networks. Journal of International Business Studies, 38(4), 673-690.

Zou, S., \& Stan, S. (1998). The determinants of export performance: a review of the empirical literature between 1987 and 1997. International Marketing Review, 15(5), 333-356.

\section{Appendix 1}

Instrument Validity results

\begin{tabular}{|c|c|c|c|}
\hline Variables & Adopted Scale & Adapted Scale & Author \\
\hline \multirow{9}{*}{$\begin{array}{l}\text { SME export perfor- } \\
\text { mance }\end{array}$} & $\begin{array}{l}\text { This export venture has been very } \\
\text { profitable. }\end{array}$ & $\begin{array}{l}\text { Our firm export has been very profita- } \\
\text { ble. }\end{array}$ & \multirow{9}{*}{$\begin{array}{l}\text { Zou, Taylor, } \\
\text { and Osland } \\
(1998)\end{array}$} \\
\hline & $\begin{array}{l}\text { This export venture has generated a } \\
\text { high volume of sales. }\end{array}$ & $\begin{array}{l}\text { Our firm export has generated a high } \\
\text { volume of sales. }\end{array}$ & \\
\hline & $\begin{array}{l}\text { This export venture has achieved } \\
\text { rapid growth. }\end{array}$ & $\begin{array}{l}\text { Our firm export has achieved rapid } \\
\text { growth. }\end{array}$ & \\
\hline & $\begin{array}{l}\text { This export venture has improved our } \\
\text { global competitiveness. }\end{array}$ & $\begin{array}{l}\text { Our firm export has improved our } \\
\text { global competitiveness. }\end{array}$ & \\
\hline & $\begin{array}{l}\text { This export venture has strengthened } \\
\text { our strategic position. }\end{array}$ & $\begin{array}{l}\text { Our firm export has strengthened our } \\
\text { strategic position. }\end{array}$ & \\
\hline & $\begin{array}{l}\text { This export venture has increased our } \\
\text { global market share. }\end{array}$ & $\begin{array}{l}\text { Our firm export has significantly in- } \\
\text { creased our global market share. }\end{array}$ & \\
\hline & $\begin{array}{l}\text { The performance of this export ven- } \\
\text { ture has been satisfactory. }\end{array}$ & $\begin{array}{l}\text { The export performance of our firm has } \\
\text { been satisfactory. }\end{array}$ & \\
\hline & $\begin{array}{l}\text { This export venture has been suc- } \\
\text { cessful. }\end{array}$ & Our firm export has been successful. & \\
\hline & $\begin{array}{l}\text { This export venture has fully met our } \\
\text { expectation. }\end{array}$ & $\begin{array}{l}\text { Our firm export has fully met our ex- } \\
\text { pectation. }\end{array}$ & \\
\hline \multirow{7}{*}{$\begin{array}{l}\text { Entrepreneurial } \\
\text { orientation }\end{array}$} & $\begin{array}{l}\text { Our company has produced more new } \\
\text { products/services for our export mar- } \\
\text { kets than our key export market com- } \\
\text { petitors during the past five years. }\end{array}$ & $\begin{array}{l}\text { Our company has produced more new } \\
\text { products for our export markets than } \\
\text { our key export market competitors dur- } \\
\text { ing the past five years. }\end{array}$ & \multirow{7}{*}{$\begin{array}{l}\text { Boso, Ca- } \\
\text { dogan, and } \\
\text { Story (2012) }\end{array}$} \\
\hline & $\begin{array}{l}\text { On average, each year we introduce } \\
\text { more new products/services in our } \\
\text { export markets than our key export } \\
\text { market competitors. }\end{array}$ & $\begin{array}{l}\text { On average, each year we introduce } \\
\text { more new products in our export mar- } \\
\text { kets than our key export market com- } \\
\text { petitors. }\end{array}$ & \\
\hline & $\begin{array}{l}\text { Industry experts would say that we are } \\
\text { more prolific when it comes to intro- } \\
\text { ducing new products/services in our } \\
\text { export markets }\end{array}$ & $\begin{array}{l}\text { Industry experts would say that we are } \\
\text { more innovative when it comes to in- } \\
\text { troducing new products in our export } \\
\text { markets. }\end{array}$ & \\
\hline & \multirow{3}{*}{$\begin{array}{l}\text { Relative to our main export competi- } \\
\text { tors, the products/services we offer in } \\
\text { our export market(s) are } \\
\text { Revolutionary } \\
\text { Inventive } \\
\text { Creative }\end{array}$} & $\begin{array}{l}\text { Relative to our main export competi- } \\
\text { tors, the products/services we offer in } \\
\text { our export market(s) are Revolutionary }\end{array}$ & \\
\hline & & $\begin{array}{l}\text { Relative to our main export competi- } \\
\text { tors, the products/services we offer in } \\
\text { our export market(s) are Inventive }\end{array}$ & \\
\hline & & $\begin{array}{l}\text { Relative to our main export competi- } \\
\text { tors, the products/services we offer in } \\
\text { our export market(s) are Creative. }\end{array}$ & \\
\hline & $\begin{array}{l}\text { Top export managers of our com- } \\
\text { pany, in general, tend to invest in high- } \\
\text { risk export projects }\end{array}$ & $\begin{array}{l}\text { Top export manager of our company, in } \\
\text { general, tend to invest in high-risk ex- } \\
\text { port projects. }\end{array}$ & \\
\hline
\end{tabular}




\begin{tabular}{|c|c|c|c|}
\hline & $\begin{array}{l}\text { This company shows a great deal of tol- } \\
\text { erance for high risk export projects }\end{array}$ & $\begin{array}{l}\text { This company shows a great deal of tol- } \\
\text { erance for high risk export projects. }\end{array}$ & \\
\hline & $\begin{array}{l}\text { Our export strategy is characterised by } \\
\text { a strong tendency to take risks }\end{array}$ & $\begin{array}{l}\text { Our export strategy is characterised by } \\
\text { a strong tendency to take risks. }\end{array}$ & \\
\hline & $\begin{array}{l}\text { Taking chances is part of our export } \\
\text { business strategy }\end{array}$ & $\begin{array}{l}\text { Taking risk is part of our export busi- } \\
\text { ness strategy. }\end{array}$ & \\
\hline & $\begin{array}{l}\text { We seek to exploit anticipated } \\
\text { changes in our export market ahead of } \\
\text { our rivals }\end{array}$ & $\begin{array}{l}\text { Our company seeks to exploit antici- } \\
\text { pated changes in our export market } \\
\text { ahead of our competitors. }\end{array}$ & \\
\hline & $\begin{array}{l}\text { We act opportunistically to shape the } \\
\text { export environment in which we oper- } \\
\text { ate }\end{array}$ & $\begin{array}{l}\text { Our company acts opportunistically to } \\
\text { shape the export environment in which } \\
\text { we operate. }\end{array}$ & \\
\hline & $\begin{array}{l}\text { We consistently try to position our- } \\
\text { selves to meet emerging export market } \\
\text { demands. }\end{array}$ & $\begin{array}{l}\text { Our company consistently tries to posi- } \\
\text { tion ourselves to meet emerging export } \\
\text { market demands. }\end{array}$ & \\
\hline \multirow{11}{*}{$\begin{array}{l}\text { Total Quality Man- } \\
\text { agement }\end{array}$} & $\begin{array}{l}\text { Managers view cost as more important } \\
\text { in comparison to the quality of prod- } \\
\text { ucts. }\end{array}$ & $\begin{array}{l}\text { Managers of our company view the cost } \\
\text { as more important in comparison to the } \\
\text { quality of products. }\end{array}$ & \multirow{11}{*}{$\begin{array}{l}\text { Shafiq et al. } \\
(2017)\end{array}$} \\
\hline & $\begin{array}{l}\text { Managers present themselves as role } \\
\text { models for the employees. }\end{array}$ & $\begin{array}{l}\text { Managers of our company present } \\
\text { themselves as role models for the em- } \\
\text { ployees. }\end{array}$ & \\
\hline & $\begin{array}{l}\text { Managers ensure that employees and } \\
\text { suppliers (the people/companies who } \\
\text { provide, e.g., raw materials to the } \\
\text { company) are aware of the company's } \\
\text { long-term plans. }\end{array}$ & $\begin{array}{l}\text { Managers of our company ensure that } \\
\text { employees are aware of the company's } \\
\text { long-term plans. }\end{array}$ & \\
\hline & $\begin{array}{l}\text { Managers do not want to give author- } \\
\text { ity to employees for them to take deci- } \\
\text { sions about their jobs. }\end{array}$ & $\begin{array}{l}\text { Managers of our company do not want } \\
\text { to give authority to employees for } \\
\text { them to take decisions about their jobs. }\end{array}$ & \\
\hline & $\begin{array}{l}\text { Managers continuously acquire and } \\
\text { update their knowledge that is valuable } \\
\text { for the organisation. }\end{array}$ & $\begin{array}{l}\text { Managers of our company continu- } \\
\text { ously acquire and update their } \\
\text { knowledge that is valuable for the or- } \\
\text { ganisation. }\end{array}$ & \\
\hline & $\begin{array}{l}\text { Managers encourage and participate in } \\
\text { continuous improvement initiatives. }\end{array}$ & $\begin{array}{l}\text { Managers of our company encourage } \\
\text { and participate in continuous improve- } \\
\text { ment initiatives. (Leadership) }\end{array}$ & \\
\hline & $\begin{array}{l}\text { The views of customers (the peo- } \\
\text { ple/companies who buy or want to buy } \\
\text { your company's products) are consid- } \\
\text { ered important while designing new } \\
\text { products. }\end{array}$ & $\begin{array}{l}\text { In our company, the views of custom- } \\
\text { ers (the people/companies who buy or } \\
\text { want to buy your company's products) } \\
\text { are considered important while design- } \\
\text { ing new products. }\end{array}$ & \\
\hline & $\begin{array}{l}\text { The views of employees and suppliers } \\
\text { are considered while shaping the com- } \\
\text { pany's objectives. }\end{array}$ & $\begin{array}{l}\text { In our company, the views of suppliers } \\
\text { are considered while shaping the com- } \\
\text { pany's objectives. }\end{array}$ & \\
\hline & $\begin{array}{l}\text { The performance of competitors and } \\
\text { best-in-class companies is assessed and } \\
\text { analysed. }\end{array}$ & $\begin{array}{l}\text { In our company, the performance of } \\
\text { competitors and best-in-class compa- } \\
\text { nies is assessed and analysed. }\end{array}$ & \\
\hline & $\begin{array}{l}\text { Systematic measurement of losses } \\
\text { (production losses, the losses due to } \\
\text { rejection of finished products, etc.) is } \\
\text { carried out. }\end{array}$ & $\begin{array}{l}\text { In our company, systematic measure- } \\
\text { ment of losses (such as production } \\
\text { losses, the losses due to rejection of } \\
\text { finished products, etc.) is carried out. }\end{array}$ & \\
\hline & $\begin{array}{l}\text { Information systems are in place to cap- } \\
\text { ture information about customers and } \\
\text { markets. }\end{array}$ & $\begin{array}{l}\text { In our company, information systems } \\
\text { are in place to capture information } \\
\text { about customers and markets. }\end{array}$ & \\
\hline
\end{tabular}


Periodically (e.g. after every three months, six months, or one year), organisational performance is evaluated against the set objectives and targets.

Formal processes are used regularly (attitude surveys, employees' briefing, etc.) to find out

employees' opinions and views.

Specific quality training is offered to employees.

Employees are encouraged to update their knowledge and skills.

Teamwork is a common practice within the organisation.

Employees have easy access to the relevant information.

Encourage the employee's opinions, suggestions about any of the activities of the organization. (People)

Suppliers are encouraged to develop long-term partnerships with the organisation.

Our organisation does not give preference to quality over cost while making purchase agreements with suppliers.

Performance of the suppliers is evaluated periodically.

Updated information and resources are provided to all employees to perform their jobs.

The organisation tries to reduce the harmful effect of its activities on the environment.

Proper procedures are established to perform different jobs.

Employees are aware of the parameters (temperature, pressure, etc.) of different processes, which are needed to be controlled for effective operation.

Performance of production processes is monitored.

Development and innovation of production processes are emphasised.

The research and development (R\&D) department is continuously working on the development and improvement of the products.

Production processes are capable of producing products according to design specifications.
In our company, periodically (e.g. after every three months, six months, or one year), organisational performance is evaluated against the set objectives and targets. (Strategy)

In our company, formal processes are used regularly (attitude surveys, employees' briefing, etc.) to find out employees' opinions and views.

In our company, specific quality training is offered to employees.

In our company, employees are encouraged to update their knowledge and skills.

In our company, teamwork is a common practice within the organisation.

In our company, employees have easy access to the relevant information.

In our company, encourage the employee's opinions, suggestions about any of the activities of the organization. (People)

In our company, suppliers are encouraged to develop long-term partnerships with the organisation.

In our company does not give preference to quality over cost while making purchase agreements with suppliers.

In our company, performance of the suppliers is evaluated periodically.

In our company, updated information and resources are provided to all employees to perform their jobs.

In our company tries to reduce the harmful effect of its activities on the environment. (Partnership and resources)

In our company, proper procedures are established to perform different jobs.

In our company, employees are aware of the parameters (temperature, pressure, etc.) of different processes, which are needed to be controlled for effective operation.

In our company, performance of production processes is monitored.

In our company, development and innovation of production processes are emphasised.

In our company, the research and development $(\mathrm{R} \& \mathrm{D})$ department is continuously working on the development and improvement of the products.

In our company, production processes are capable of producing products according to design specifications. 


\begin{tabular}{|c|c|c|c|}
\hline & $\begin{array}{l}\text { Proper systems are in place to deal with } \\
\text { customer complaints. }\end{array}$ & $\begin{array}{l}\text { In our company, proper systems are in } \\
\text { place to deal with customer complaints. } \\
\text { (Process) }\end{array}$ & \\
\hline \multirow{15}{*}{ Business network } & $\begin{array}{l}\text { We ask our business partners when we } \\
\text { need information regarding any of the } \\
\text { following: new business opportunities, } \\
\text { competition or technology develop- } \\
\text { ments in the market. }\end{array}$ & $\begin{array}{l}\text { Our firm asks to business partners when } \\
\text { we need information regarding any of } \\
\text { the following: new business opportuni- } \\
\text { ties, competition or technology devel- } \\
\text { opment in the market. }\end{array}$ & \multirow{15}{*}{$\begin{array}{l}\text { Thornton, } \\
\text { Henneberg, } \\
\text { and Naude } \\
(2014)\end{array}$} \\
\hline & $\begin{array}{l}\text { Information provided by our business } \\
\text { partners is helpful for us to make an in- } \\
\text { formed decision. }\end{array}$ & $\begin{array}{l}\text { Information provided by our business } \\
\text { partners is helpful for us to make an in- } \\
\text { formed decision. }\end{array}$ & \\
\hline & $\begin{array}{l}\text { By speaking to our business contacts, } \\
\text { we are able to obtain the information } \\
\text { that is crucial to us. }\end{array}$ & $\begin{array}{l}\text { By speaking to our business contacts, } \\
\text { our firm is able to obtain the infor- } \\
\text { mation that is crucial to us. }\end{array}$ & \\
\hline & $\begin{array}{l}\text { Information from our business contacts } \\
\text { who work in a similar market can be } \\
\text { useful for us. }\end{array}$ & $\begin{array}{l}\text { Information from our business contacts } \\
\text { who work in a similar market can be } \\
\text { useful for us. }\end{array}$ & \\
\hline & $\begin{array}{l}\text { We make every effort to go out and net- } \\
\text { work in order to increase our reputation } \\
\text { in the market. }\end{array}$ & $\begin{array}{l}\text { Our firm makes every effort to go out } \\
\text { and network in order to increase our } \\
\text { reputation in the market. }\end{array}$ & \\
\hline & $\begin{array}{l}\text { We recognize that the value of working } \\
\text { well with our business partners adds to } \\
\text { the reputation of our products or ser- } \\
\text { vices. }\end{array}$ & $\begin{array}{l}\text { Our firm recognizes that the value of } \\
\text { working well with our business part- } \\
\text { ners adds to the reputation of our prod- } \\
\text { ucts. }\end{array}$ & \\
\hline & $\begin{array}{l}\text { We invest in building up our reputation } \\
\text { in the market by networking with our } \\
\text { business partners. }\end{array}$ & $\begin{array}{l}\text { Our firm invests in building up our rep- } \\
\text { utation in the market by networking } \\
\text { with our business partners. }\end{array}$ & \\
\hline & $\begin{array}{l}\text { We work toward becoming an effective } \\
\text { business partner for other companies in } \\
\text { the market (e.g., potential customers or } \\
\text { suppliers). }\end{array}$ & $\begin{array}{l}\text { Our firm works toward becoming an ef- } \\
\text { fective business partner for other com- } \\
\text { panies in the market (e.g., potential cus- } \\
\text { tomers or suppliers). }\end{array}$ & \\
\hline & $\begin{array}{l}\text { Matching our suppliers' capacity to the } \\
\text { demands of our customers has been an } \\
\text { important practice in our organization. }\end{array}$ & $\begin{array}{l}\text { Matching our suppliers' capacity to the } \\
\text { demands of our customers has been an } \\
\text { important practice in our organization. }\end{array}$ & \\
\hline & $\begin{array}{l}\text { Our suppliers' ability is critical for us to } \\
\text { satisfy our customers. }\end{array}$ & $\begin{array}{l}\text { Our suppliers' ability is critical for us to } \\
\text { satisfy our customers. }\end{array}$ & \\
\hline & $\begin{array}{l}\text { Having good relationships with both } \\
\text { suppliers and customers has enabled us } \\
\text { to adapt to changes in the market place. }\end{array}$ & $\begin{array}{l}\text { Our firm has good relationships with } \\
\text { both suppliers and customers, has ena- } \\
\text { bled us to adapt to changes in the mar- } \\
\text { ket place. }\end{array}$ & \\
\hline & $\begin{array}{l}\text { Our customer-focused approach is } \\
\text { communicated to suppliers, so that they } \\
\text { are aware of how we serve our custom- } \\
\text { ers and can contribute to the success of } \\
\text { delivering the offerings. }\end{array}$ & $\begin{array}{l}\text { Our customer-focused approach is } \\
\text { communicated to suppliers, so that they } \\
\text { are aware of how we serve our custom- } \\
\text { ers and can contribute to the success of } \\
\text { delivering the offerings. }\end{array}$ & \\
\hline & $\begin{array}{l}\text { We initiate relationships with new busi- } \\
\text { ness partners to gain local knowledge in } \\
\text { a new market. }\end{array}$ & $\begin{array}{l}\text { Our firm initiates relationships with } \\
\text { new business partners to gain local } \\
\text { knowledge in a new market. }\end{array}$ & \\
\hline & $\begin{array}{l}\text { We interact with the customers of our } \\
\text { customers. }\end{array}$ & $\begin{array}{l}\text { Our firm interacts with the customers of } \\
\text { our customers }\end{array}$ & \\
\hline & $\begin{array}{l}\text { We work closely with influential par- } \\
\text { ties who have relationships with our di- } \\
\text { rect customers to stimulate demand. }\end{array}$ & $\begin{array}{l}\text { Our firm works closely with influential } \\
\text { parties who have relationships with our } \\
\text { direct customers to stimulate demand. }\end{array}$ & \\
\hline
\end{tabular}




\begin{tabular}{|c|c|c|c|}
\hline & $\begin{array}{l}\text { Identifying our competitors' major cus- } \\
\text { tomers helps us to getting to know the } \\
\text { needs and requirements of potential }\end{array}$ & $\begin{array}{l}\text { Identifying our competitors' major cus- } \\
\text { tomers helps us to getting to know the } \\
\text { needs and requirements of potential }\end{array}$ & \\
\hline \multirow{13}{*}{$\begin{array}{l}\text { Export market ori- } \\
\text { entation }\end{array}$} & $\begin{array}{l}\text { In this company, we generate a lot of } \\
\text { information concerning trends (e.g., } \\
\text { regulations, technological develop- } \\
\text { ments, political, economic) in our ex- } \\
\text { port markets. }\end{array}$ & $\begin{array}{l}\text { In our firm, we generate a lot of infor- } \\
\text { mation concerning trends (e.g. regula- } \\
\text { tions, technological developments, po- } \\
\text { litical, economic) in our export mar- } \\
\text { kets. }\end{array}$ & \multirow{13}{*}{$\begin{array}{l}\text { Cadogan et al. } \\
(2001)\end{array}$} \\
\hline & $\begin{array}{l}\text { We constantly monitor our level of } \\
\text { commitment and orientation to serving } \\
\text { export customer needs. }\end{array}$ & $\begin{array}{l}\text { Our firm constantly monitors our level } \\
\text { of commitment and orientation to serv- } \\
\text { ing export customer needs. }\end{array}$ & \\
\hline & $\begin{array}{l}\text { We are slow to detect fundamental } \\
\text { shifts in our export environment (e.g., } \\
\text { regulation, technology, economy). }\end{array}$ & $\begin{array}{l}\text { Our firm is slow to detect fundamental } \\
\text { shifts in our export environment (e.g. } \\
\text { regulation, technology, economy). }\end{array}$ & \\
\hline & $\begin{array}{l}\text { We periodically review the likely effect } \\
\text { of changes in our export environment } \\
\text { (e.g., regulation, technology). }\end{array}$ & $\begin{array}{l}\text { Our firm periodically reviews the likely } \\
\text { effect of changes in our export environ- } \\
\text { ment (e.g. regulation, technology). }\end{array}$ & \\
\hline & $\begin{array}{l}\text { We generate a lot of information in or- } \\
\text { der to understand the forces which in- } \\
\text { fluence our overseas customers' needs } \\
\text { and preferences. }\end{array}$ & $\begin{array}{l}\text { Our firm generates a lot of information } \\
\text { in order to understand the forces that in- } \\
\text { fluence our overseas customers' needs } \\
\text { and preferences. }\end{array}$ & \\
\hline & $\begin{array}{l}\text { Too much information concerning our } \\
\text { export competitors is discarded before } \\
\text { it reaches decision makers. }\end{array}$ & $\begin{array}{l}\text { Too much information concerning our } \\
\text { export competitors is discarded before } \\
\text { it reaches top management. }\end{array}$ & \\
\hline & $\begin{array}{l}\text { Information which can influence the } \\
\text { way we serve our export customers } \\
\text { takes forever to reach export personnel. }\end{array}$ & $\begin{array}{l}\text { Information which can influence the } \\
\text { way we serve our export customers } \\
\text { takes forever to reach export personnel. }\end{array}$ & \\
\hline & $\begin{array}{l}\text { Important information about our export } \\
\text { customers is often "lost in the system." }\end{array}$ & $\begin{array}{l}\text { Important information about our export } \\
\text { customers is often 'lost in the system'. }\end{array}$ & \\
\hline & $\begin{array}{l}\text { Information about our export competi- } \\
\text { tors' activities often reaches relevant } \\
\text { personnel too late to be of any use. }\end{array}$ & $\begin{array}{l}\text { Information about our export competi- } \\
\text { tors' activities often reaches relevant } \\
\text { personnel too late to be of any use. }\end{array}$ & \\
\hline & $\begin{array}{l}\text { Important information concerning ex- } \\
\text { port market trends (regulation, technol- } \\
\text { ogy) is often discarded as it makes its } \\
\text { way along the communication chain. }\end{array}$ & $\begin{array}{l}\text { Important information concerning ex- } \\
\text { port market trends (regulation, technol- } \\
\text { ogy) is often discarded as it makes its } \\
\text { way along the communication chain. }\end{array}$ & \\
\hline & $\begin{array}{l}\text { If a major competitor were to launch } \\
\text { an intensive campaign targeted at our } \\
\text { foreign customers, we would imple- } \\
\text { ment a response immediately. }\end{array}$ & $\begin{array}{l}\text { If a major competitor were to launch an } \\
\text { intensive campaign targeted at our for- } \\
\text { eign customers, we would implement a } \\
\text { response immediately. }\end{array}$ & \\
\hline & $\begin{array}{l}\text { We are quick to respond to significant } \\
\text { changes in our competitors' price } \\
\text { structures in foreign markets. }\end{array}$ & $\begin{array}{l}\text { Our firm is quick to respond to signifi- } \\
\text { cant changes in our competitors' price } \\
\text { structures in foreign markets. }\end{array}$ & \\
\hline & $\begin{array}{l}\text { We rapidly respond to competitive ac- } \\
\text { tions that threaten us in our export mar- } \\
\text { kets. }\end{array}$ & $\begin{array}{l}\text { Our firm rapidly responds to competi- } \\
\text { tive actions that threaten us in our ex- } \\
\text { port markets. }\end{array}$ & \\
\hline
\end{tabular}

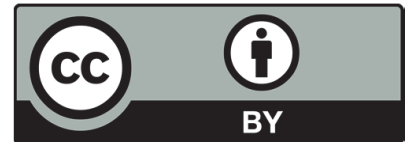

(C) 2017 by the authors; licensee Growing Science, Canada. This is an open access article distributed under the terms and conditions of the Creative Commons Attribution (CCBY) license (http://creativecommons.org/licenses/by/4.0/). 